\title{
HUBUNGAN ANTARA TINGKAT PENGETAHUAN IBU TENTANG GIZI DENGAN STATUS GIZI BALITA DI PUKESMAS PAL III KABUPATEN PONTIANAK TAHUN 2018
}

\author{
Alexander ${ }^{1}$, Melyani $^{2}$ \\ Akademi Kebidanan Panca Bhakti Pontianak \\ Email korespondensi: akbidpbpontianak@gmail.com
}

\begin{abstract}
Abstrak
Status gizi adalah status kesehatan yang dihasilkan oleh keseimbangan antara kebutuhan dan masukan nutrient. di Pukesmas Pal III didapatkan 10 balita dengan gizi kurang dilihat dari tinggi badan dan berat badan yang tidak sesuai dengan usia. Tujuan dari penetlitian ini adalah untuk mengetahui hubungan antara pengetahuan ibu tentang gizi dengan status gizi balita dipukesmas Pal III Pontianak Tahun 2018.Penelitian ini menggunakan desain penelitian analitik korelasi dengan pendekatan korelasi dengan pendekatan cross sectional, sampel dalam penelitian ini sebanyak 57 sampel. Hasil penelitian diperoleh sangat sedikit dari responden $(10,5 \%)$ yaitu 6 responden berpengetahuan baik. Sebagian besar dari responden (78\%) yaitu 45 responden dengan Status Gizi normal. Dari hasil penelitian di peroleh nilai p value $(0,600)>$ nilai alpha $(0,005)$, hal ini berarti bahwa hipotesis nol (Ho) diterima dan Ha di tolak. Peneliti menyimpulkan bahwa tidak ada hubungan yang signifikan antara pengetahuan tentang gizi seimbang dengan status gizi. Diharapakan Pukesmas Pal III bisa memberikan penyuluhan pada saat posyandu dengan memberikan materi tentang pentingnya konsumsi gizi seimbang pada balita dan menganjurkan kepada ibu-ibu agar melakukan pemantauan status gizi pada balita secara berkala di tempat pelayanan kesehatan.
\end{abstract}

Kata Kunci: Pengetahuan, Status Gizi, Pukesmas Pal III, 2018

\section{Pendahuluan}

Gizi adalah elemen yang terdapat dalam makanan dan dapat dimanfaatkan secara langsung oleh tubuh seperti hal nya karbohidrat, protein, lemak, vitamin, mineral, dan air. Makanan bergizi merupakan komponen utama untuk membantu tumbuh kembang manusia terutama bagi anak-anak (balita). Untuk memaksimalkan tumbuh kembang anak makanan bergizi sangat diharuskan dikonsumsi mulai masa kehamilan hingga anak lahir 0-2 tahun. Pada usia 0-2 tahun adalah masa paling baik untuk memaksimalkan pertumbuhan sel otak dan gizi yang baik dan cukup. Makanan bergizi dan gizi yang baik tidak hanya dapat dikonsumsi oleh anak-anak tetapi oleh semua jenis usia. Gizi seimbang yaitu gizi yang sesuai dengan

\footnotetext{
${ }^{1}$ Dosen Akademi Kebidanan Panca Bhakti Pontianak

2 Dosen Akademi Kebidanan Panca Bhakti Pontianak
}

kebutuhan tubuh melalui makanan sehari-hari sehingga tubuh bisa aktif, sehat optimal, tidak terganggu penyakit dan tubuh tetap sehat. yang dapat dipenuhi dengan pemberian makanan (Irianto, 2014).

Status gizi adalah status kesehatan yang dihasilkan oleh keseimbangan antara kebutuhan dan masukan nutrient (Beck 2002 dalam Jafar 2010). Pada masa ini otak balita telah siap menghadapi berbagai stimuli seperti belajar berjalan dan berbicara lebih lancar. Perlunya perhatian lebih dalam tumbuh kembang diusia balita didasarkan fakta bahwa kurang gizi yang terjadi pada masa emas ini, bersifat irreversible (tidak dapat pulih). Anak dibawah lima tahun (balita) merupakan kelompok yang menunjukan pertumbuhan 
berat badan yang pesat, sehingga memerlukan zat-zat gizi yang tinggi setiap kilogram berat badannya. Usia balita juga membutuhkan gizi seimbang yaitu makanan yang mengandung zat-zat gizi yang dibutuhkan sesuai usia. Makanan seimbang pada usia ini perlu diterapkan karena akan berpengaruh kualitas pada usia dewasa sampai lanjut (Irianto, 2014).

Menurut Soedjatmiko di dalam Irianto (2014), agar proses tumbuh-kembang dapat berjalan dengan optimal, seorang anak harus mendapatkan pemenuhan gizi balita dari tiga kebutuhan pokoknya, yaitu, pertama, adalah kebutuhan fisik-biologis, berupa kebutuhan akan nutrisi (ASI, makanan pengganti ASI/ makanan pendamping ASI, imunisasi, serta kebersihan fisik dan lingkungan. Kedua adalah kebutuhan emosi berupa kasih sayang rasa nyaman dan aman, dihargai, diperhatikan serta didengar keingginan dan pendapatnya. Ketiga yang tak kalah penting adalah kebutuhan akan stimulasi yang mencakup aktivitas bermain untuk meransang semua indra, mengasah motorik halus dan kasar, melatih keterampilan, berkomunikasi, kemandirian berpikir dan berkreasi.

Menurut Almatsier (2002), Gizi tidak seimbang pada balita dapat menyebabkan Kekurangan energi dan protein sehingga mengakibatkan pertumbuhan dan perkembangan balita terganggu. Gangguan asupan gizi yang bersifat akan menyebabkan anak kurus kering yang disebut Wasting. Wasting, berat badan tidak sebanding dengan tinggi badan. Kekurangan energi protein akut dengan derajat berat dapat dibedakan 3 bentuk yaitu Marasmus, Kwashior, Marasmuskwashior dan Obesitas. Timbulnya obesitas dipengaruhi oleh beberapa faktor diantaranya faktor keturunan dan lingkungan (Irianto,2014).

Status gizi balita dapat dipengaruhi oleh pengaruh ibu yaitu dengan kurangnya pengetahuan dan keterampilan yang mempengaruhi gizi dalam bidang memasak, budaya tentang adanya pantangan, sosial ekonomi keluarga, adanya penyakit pada anak yang menyebabkan tergangu status gizi balita, jenis dan jumlah makanan yang diberikan (Marmi 2013).

Pengetahuan seorang ibu tentang gizi buruk sangat perlu karena dapat melihat pertumbuhan dan perkembangan balita. Bahaya pada balita pada penyebabnya seperti asupan gizi yang baik dapat memicu kesalahan dalam memberikan asupan makanan kepada anak dalam jumlah banyak tapi tanpa memperhatikan kandungan nutrisi yang ada di dalam makanan tersebut (Hasdianah, 2014).

Anak yang kurang mendapat asupan gizi pertumbuhan dan perkembangan terhambat dari pada anak yang mendapat asupan yang cukup. Seperti saja pertumbuhan meliputi tinggi badan, berat badan balita rendah, perkembangan otak, tingkat kecerdasan dan menderita gizi buruk akan mengalami penurun daya tahan tubuh sehingga rentan terhadap penyakit infeksi. Cakupan pelayanan kesehatan terutama penanganan diare, tindakan cepat pada balita yang tidak naik berat badan, pendidikan, penyuluhan kesehatan dan gizi. Banyaknya 
penyakit menular seperti demam berdarah, diare, polio, malaria dan sebagainya. Secara hampir bersamaan di mana-mana, resikonya meninggal dari anak yang gizi buruk, 13 kali besar dibandingkan dengan anak normal (Adisasmito, 2007)

Kesehatan seorang balita sangat dipengaruhi oleh gizi yang terserat didalam tubuh kurangnya gizi yang diserap oleh tubuh mengakibatkan mudah terserang penyakit karena gizi memberi pengaruh yang besar terhadap kekebalan tubuh. Gizi bukan hanya mempengaruhi kesehatan tubuh, tetapi dapat juga mempengaruhi kecerdasan, apabila gizi yang diperlukan oleh otak tidak terpenuhi, otak akan mengalami pengaruh sehingga tidak dapat berkembang (Sibagariang, 2010).

Menurut Pedoman Gizi Seimbang tahun 2016 yang menyediakan data dan informasi status gizi balita. Balita yang memiliki tinggi badan dan berat badan ideal (TB/U normal dan $\mathrm{BB} / \mathrm{TB}$ normal) jumlahnya $61,1 \%$. Masih ada $38,9 \%$ Balita di Indonesia yang masih mengalami masalah gizi, terutama Balita dengan tinggi badan dan berat badan (pendek normal) sebesar $23,4 \%$ yang berpotensi akan mengalami kegemukan. Prevalensi gizi buruk dan gizi kurang pada Balita, terdapat 3,4\% Balita dengan gizi buruk dan $14,4 \%$ gizi kurang. Masalah gizi buruk-kurang pada Balita di Indonesia merupakan masalah kesehatan masyarakat yang masuk dalam kategori sedang (Indikator World Health Organization diketahui masalah gizi buruk-kurang sebesar $17,8 \%)$. Prevalensi balita pendek cenderung tinggi, dimana terdapat $8,5 \%$ balita sangat pendek dan 19,0\% balita pendek. Masalah Balita pendek di Indonesia merupakan masalah kesehatan masyarakat masuk dalam kategori masalah kronis (Berdasarkan WHO masalah Balita pendek sebesar 27,5\%). Pravalensi balita kurus cukup tinggi dimana terdapat 3,1\% balita yang sangat kurus dan 8,0\% Balita yang kurus. Masalah Balita kurus di Indonesia merupakan masalah kesehatan masyarakat yang masuk dalam kategori akut (Profil Kesehatan Indonesia tahun 2016).

Berdasarkan hasil laporan program gizi Dinas Kesehatan Provinsi Kalimantan Barat Tahun 2015, dari seluruh Kabupaten/Kota yang ada terdapat kasus gizi buruk sebanyak 397 kasus. Angka tersebut didapatkan dari laporan kasus dilihat berdasarkan tanda-tanda klinis kasus gizi buruk. Kasus gizi buruk terbanyak ada di Kabupaten Kapuas Hulu yaitu sebanyak 114 kasus, diikuti oleh Kabupaten Ketapang sebanyak 69 kasus dan Kabupaten Kubu Raya 30 kasus. Kabupaten lainnya rata-rata masih dibawah 30 kasus. Dilihat dari gizi buruk yang mendapat perawatan, seluruh balita gizi buruk mendapat perawatan sesuai prosedur tatalaksana gizi buruk (100\%) (Profil Kesehatan Propinsi Kalbar tahun 2015).

Bedasarkan hasil Riset Kesehatan Dasar Tahun 2014 pravelensi berat kurang (Underweight) secara nasional adalah 19,6\% terdiri dari $5,7 \%$ gizi buruk dan $13,9 \%$ gizi kurang. Jika dibandingkan dengan angka prevalensi nasional tahun 2007(18,4\%) dan tahun 2010 (17,9\%) meningkat. Perubahan terutama pada prevalensi gizi buruk yaitu dari 5,4\% tahun 2007, 4,9\% pada tahun 2010 dan $5,7 \%$ tahun 2013 sedangkan prevalensi gizi 
kurang naik sebesar 5,9\% dari 2007 dan 2013 sedangkan prevalensi gizi kurang secara nasional harus di turunkan sebesar $4,1 \%$ dalam periode 2013-2015. (Profil Kesehatan Provinsi kalbar tahun 2015)

Penelitian lain yang dilakukan Lailatul dengan judul "Hubungan Tingkat Antara Tingkat Pengetahuan Gizi Ibu, Pola Makan Balita Dengan Status Gizi Balita di Wilayah Kerja Puskesmas Kedungwuni II Kabupaten Pekalongan Tahun 2016" di dapatkan hasil ada hubungan antara tingkat pengetahuan gizi ibu dan pola makan balita dengan status gizi balita. Berdasarkan hasil penelitian saran yang diajukan adalah penyuluhan tentang keluarga sadar gizi (Kadarzi) untuk meningkatkan pengetahuan masyarakat khususnya ibu serta perlunya pemantauan status gizi pada balita secara berkala oleh sub bagian gizi sehingga keadaan status gizi balita dapat diketahui dan segera dilakukan penanggulangan apabila terjadi penurunan status gizi di wilayah kerjanya. (Lailatul 2016).

Berdasarkan data dari Pukesmas Pal III Pontianak pada tahun 2018 didapatkan pada bulan Januari-Febuari 2018 sebanyak 137 balita yang diukur berat badan di Pukesmas Pal III dan didapatkan 10 balita dengan gizi kurang dilihat dari tinggi badan dan berat badan yang tidak sesuai dengan usia.

Hasil studi pendahuluan dengan mewawancarai 5 orang ibu diperoleh hasil hanya 2 orang ibu yang mengetahui tentang hal-hal yang berhubungan dengan gizi pada balita seperti pengertian gizi seimbang, makanan yang baik dan dampak kurang gizi pada balita. Halini menunjukan bahwa masih ada ibu-ibu yang kurang mengetahui tentang gizi pada balita, peneliti juga mendapatkan bahwa masih ada balita yang memiliki berat badan tidak sesuai dengan usia sebanyak 10 orang.

Bedasarkan latar belakang diatas dimana diperoleh masih ada ibu-ibu yang pengetahuannya masih rendah dan masih ada bayi dengan gizi kurang, sehingga membuat peneliti tertarik untuk meneliti tentang Hubungan Antara Tingkat Pengetahuan Ibu Tentang Gizi Dengan Status Gizi Dengan Status Gizi Balita di Pukesmas Pal III Pontianak.

\section{Metode}

Desain penelitian ini menggunakan analitik korelasi dengan pendekatan cross sectional. Studi cross sectional hanya merupakan salah satu studi observasional untuk mengetahui hubungan antara variabel dependen dengan independen pada situasi atau subjek tertentu. Populasi dalam penelitian ini dari bulan Januari - Maret sebanyak 137 orang ibu- ibu yang mempunyai balita di Pukesmas Pal III. Sampel yang diambil sebanyak 57 orang. Pengumpulan data menggunakan kuesioner kemudian diolah dan dianalisis menggunakan analisis univariat serta analisis bivariat menggunakan uji chi square. 
Hasil dan Pembahasan

Tabel 1 Pengetahuan responden tentang Gizi di Pukesmas Pal III Pontianak Tahun 2018

\begin{tabular}{lccc}
\hline & \multirow{2}{*}{ Pengetahuan } & \multicolumn{2}{c}{ Jumlah } \\
\cline { 2 - 3 } & & $\mathrm{N}$ & $\%$ \\
\hline Baik $(76-100 \%)$ & 6 & 10,5 \\
Cukup $(56-75 \%)$ & 26 & 45,6 \\
Kurang $(<56 \%)$ & 25 & 43,9 \\
\hline
\end{tabular}

Bedasarkan tabel dapat diketahui bahwa sebagian dari responden dari responden memiliki pengetahuan yang cukup yaitu

sebanyak 26 orang $(45,6 \%)$ dan sangat sedikit dari responden yang memiliki pengetahuan baik sebanyak 6 orang $(10,5 \%)$.

Tabel 2. Status Gizi Balita di Pukesmas Pal III Pontianak Tahun 2018

\begin{tabular}{llll}
\hline & Status Gizi & \multicolumn{2}{c}{ Jumlah } \\
\cline { 2 - 4 } & & $\mathrm{N}$ & $\%$ \\
\hline Tidak Normal & 12 & 22 \\
Normal & 45 & 78 \\
\hline
\end{tabular}

Berdasarkan tabel dapat diketahui bahwa sebagian besar dari responden (78\%) yaitu 45 responden dengan Status Gizi normal, dan

Tabel 3. Hubungan Tingkat Pengetahuan Ibu Tentang Gizi Dengan Status Gizi Balita Di Pukesmas Pal III Tahun 2018

\begin{tabular}{|c|c|c|c|c|c|c|}
\hline \multirow[t]{3}{*}{ Pengetahuan } & \multicolumn{4}{|c|}{ Status Gizi } & \multirow{3}{*}{$\mathrm{P}$ value } & \multirow{3}{*}{$\alpha$} \\
\hline & \multicolumn{2}{|c|}{ Normal } & \multicolumn{2}{|c|}{ Tidak } & & \\
\hline & $\mathrm{N}$ & $\%$ & $\mathrm{~N}$ & $\%$ & & \\
\hline Baik & 4 & 8,9 & 2 & $16,7 \%$ & & \\
\hline Cukup & 22 & 48,9 & 4 & $33,3 \%$ & 0,600 & 0,05 \\
\hline Kurang & 19 & 42,2 & 6 & $50 \%$ & & \\
\hline
\end{tabular}

Berdasarkan tabel diperoleh bahwa 4 responden yang berpengetahuan baik dengan 2 responden berpengetahuan baik dengan Status Gizi tidak normal, dan sebagian dari responden yaitu 22 responden yang berpengetahuan cukup dengan Status Gizi normal sebagian kecil dari responden yaitu 4 responden yang berpengetahuan cukup dengan Status Gizi tidak normal.

Dari hasil penelitian menunjukan bahwa hasil analisa dengan komputerisasi, sebagian kecil dari responden (22\%) yaitu 12 responden dengan status gizi tidak normal. 
yaitu 26 responden berpengetahuan cukup dan $(43,9 \%)$ yaitu 25 reponden berpengetahuan kurang.

Menurut Notoamodjo (2010), pengetahuan adalah hasil pengindraan, atau hasil tahu seseorang terhadap nilai objek melalui indera yang dimilikinya (mata, hidung, telinga, dan sebagainya) dengan sendirinya pada waktu penginraan sampai menghasilkan pengetahuan tersebut sangan di pengaruhi oleh intensitas perhatian dan presepsi terhadap objek. Sebagian besar pengetahuan seseorang diperoleh melalui indra pendengaran (telinga) dan indra penglihatan (mata). Menurut Sadiaoetama (2010), status gizi diartikan sebagai keadaan tubuh yang merupakan hasil akhir dari keseimbangan antara zat gizi yang masuk dalam tubuh dan utilasinya. Status gizi sangan ditentukan oleh ketersediaan zat gizi dalam jumlah cukup dan dalam kombinasi waktu yang tepat ditingkat sel tubuh agar berkembang dan berfungsi secara normal.

Menurut Almatsier (2010), Pengetahuan Gizi adalah sesuatu yang diketahui tentang makanan dalam hubungannya dengan kesehatan optimal. Pengetahuan gizi meliputi pengetahuan tentang pemilihan dan konsumsi sehari-hari dengan baik dan memberikan semua zat gizi yang di butuhkan untuk fungsi normal tubuh. Pemilihan dan konsumsi bahan makanan berpengaruh terhadap status gizi seseorang. Pengetahuan tentang gizi buruk seorang ibu sangat perlu karena dapat melihat pertumbuhan dan perkembangan balita. Bahaya pada balita pada penyebabnya seperti asupan gizi yang baik dapat memicu kesalahan dalam memberikan asupan makanan kepada anak dalam jumlah banyak tapi tanpa memperhatikan kandungan nutrisi yang ada di dalam makanan tersebut (Hasdianah,2014).

Penelitian ini sependapat dengan Wahyani tahun 2014 tentang Hubungan Pengetahuan Ibu Tentang Gizi Dengan Status Gizi Balita Diwilayah Kerja Pukesmas Pleret Bantul Tahun 2014 menunjukan bahwa sebagian 245 orang memiliki pengetahuan yang cukup dan sebanyak 9 orang yang berpengetahuan baik. Hal ini menunjukan responden lebih sering di rumah dari pada berada di luar rumah sehingga memungkinkan mempunyai pengetahuan terbatas, lingkungan rumah jika tidak ditunjang dengan mencari informasi tambahan melalui media informasi yang dimilikinya seperti radio dan televisi atau membaca buku-buku terutama buku tentang kesehatan yang berkaitan dengan gizi.

Ibu rumah tangga sebenarnya mempunyai waktu lebih banyak untuk menambah wawasan dan pengetahuan sehingga dapat meningkatkan pengetahuan karena pengetahuan akan mempengaruhi prilaku. Dan faktor-faktor yang mempengaruhi prilaku seseorang menurut Notoadmodjo(2007) yaitu faktor Predisposisi yang terwujud dalam pengetahuan, sikap, kepercayaan, keyakinan dan nilai lain-lainnya ada juga faktor pendukung yang terwujud dalam lingkungan fisik,tersedia atau tidak tersedianya fasilitas-fasilitas atau sarana kesehatan dan yang terakhir faktor pendorong yang terwujud dalam sikap dan prilaku 
petugas kesehatan atau petugas lain, yang merupakan kelompok referensi dari prilaku masyarakat.

Responden dengan pengetahuan kurang bisa di sebabkan karena ibu-ibu tidak pernah mendapatkan penyuluhan dan tidak berkonsultasi pada petugas kesehatan untuk mendapatkan pengetahuan/informasi tentang makanan yang baik untuk balita supaya tidak ada lagi balita dengan status gizi tidak normal, sehingga tidak menutup kemungkinan, dapat mempengaruhi tingkat pengetahuan ibu tentang gizi seimbang. Hal ini di dukung oleh pendapat dari Notoadmodjo (2010) yang menyatakan bahwa salah satu faktor yang bisa mempengaruhi pengetahuan yaitu (media) informasi dimana media/informasi, Informasi yang di peroleh baik dari pendidikan formal maupun non formal dapat memberikan pengaruh jangka pendek sehingga menghasilkan perubahan atau peningkatan pengetahuan, majunya teknologi akan tersedia macam,-macam media massa yang dapat mempengaruhi pengetahuan masyarakat tentang inovasi baru. Bagi ibu yang masih memiliki balita yang status gizi tidak normal sebaiknya diharapkan aktif mengikuti penyuluhan tentang gizi.

Status gizi pada balita di pukesmas pal III di pontianak menunjukan bahwa sebagian besar dari reponden (78) yaitu 45 responden dengan status gizi normal, sedikit dari responden (22) dengan status gizi tidak normal yaitu 12 responden. Status gizi diartikan sebagai keadaan tubuh yang merupakan hasil akhir dari keseimbangan antara zat gizi yang masuk dalam tubuh dan utilasinya. Status gizi sangan ditentukan oleh ketersediaan zat gizi dalam jumlah cukup dan dalam kombinasi waktu yang tepat ditingkat sel tubuh agar berkembang dan berfungsi secara normal. Status gizi ditentukan oleh sepenuhnya zat gizi yang diperlukan tubuh dan faktor yang menentukan besarnya kebutuhan, penyerapan dan penggunaan zatzat tersebut (Sediaoetama,2010)

Gizi buruk pada anak balita disebut juga kurang energi protein, ditandai dengan kondisi berat badan kurang berat dari berat seharusnya (berat badan pada KMS berada dibawah garis merah atau pita kuning bagian bawah. Kesehatan seorang balita sangat dipengaruhi oleh gizi yang terserat didalam tubuh kurangnya gizi yang diserap oleh tubuh mengakibatkan mudah terserang penyakit karena gizi memberi pengaruh yang besar terhadap kekebalan tubuh. Gizi bukan hanya mempengaruhi kesehatan tubuh, tetapi dapat juga mempengaruhi kecerdasan, apabila gizi yang diperlukan oleh otak tidak terpenuhi, otak akan mengalami pengaruh sehingga tidak dapat berkembang. Status gizi yang tidak normal pada bayi di pukesmas Pal III bisa di sebabkan oleh faktor pendidikan, ekonomi, keterpaparan informasi atau pengetahuan yang terbatas tentang asupan gizi baik dapat memicu kesalahan dalam memberi makanan pada anak. Bisa saja orang tua memberikan asupan makanan kepada anak dalam jumlah banyak tetapi tanpa memperhatikan kandungan nutrisi yang ada dalam makanan tersebut. Dan juga faktor ekonomi, orang tua balita tidak mampu untuk memberikan nutrisi yang baik karena masalah biaya yang 
diprioritaskan untuk memenuhi kecukupan konsums seluruh anggota keluarganya.

Untuk bayi yang status gizi tidak normaldi Puskesmas Pal III agar ibu-ibu bisa memberikan makanan utama untuk proses pemulihan yang padat gizi, makanan berupa karbohidrat, protein serta lemak, menganjurkan kepada orang tua untuk rajin mengikuti posyandu agar mengetahui status pertumbuhan dan perkembagan bayinya. Hasil penelitian didapatkan bahwa di Pukemas Pal III masih ada balita yang status gizi nya yang tidak normal yaitu sebanyak (22) yaitu 12 responden yang terdiri dari 1 responden gizi buruk, 8 responden gizi kurang, dan 3 responden obesitas, hal ini bisa disebabkan karena kesukaan jenis makanan yang dikonsumsi balita tidak sesuai dengan gizi, sosial ekonomi keluarga yang menjadi keterbatasan penghasilan keluarga dan mutu makanan yang di sajikan tidak terlalu mengandung nilai gizi yang sesuai umur balita dan pengetahuan seorang ibu kurang sehingga memberikan balitanya makanan yang gizi nya kurang. Hal ini sehingga tidak menutup kemungkinan, dapat mempengaruhi status gizi balita.

Berdasarkan hasil analisis hubungan antara tingkat pengetahuan ibu tentang gizi dengan status gizi balita di Pukesmas Pal III pontianak yaitu pengetahuan gizi seimbang di dapatkan bahwa 4 responden yang berpengetahuan baik dengan Status Gizi normal, sangat sedikit dari responden yaitu 2 responden berpengetahuan baik dengan Status Gizi tidak normal, dan sebagian dari responden yaitu 22 responden yang berpengetahuan cukup dengan Status Gizi normal sebagian kecil dari responden yaitu 4 responden yang berpengetahuan cukup dengan Status Gizi tidak normal.

Dari hasil penelitian menunjukan bahwa hasil analisa dengan komputerisasi, dengan taraf signifikasi $5 \%$ di peroleh nilai $\mathrm{p}$ value 0,600 dan nilai alpha $(\alpha)$ sebesar 0,05 . Dalam penelitian ini didapatkan nilai $\mathrm{p}$ value $>$ nilai alpha $(\alpha)$. Hal ini berarti bahwa hipotesis nol (Ho) diterima dan Ha di tolak, sehingga dapat disimpulkan bahwa tidak ada hubungan yang signifikan antara pengetahuan tentang gizi seimbang dengan status gizi sehingga di dapatkan juga bahwa status gizi balita dengan pengetahuan ibu tidak terdapat perbedaan yang signifikan.

Tingkat konsumsi ditentukan oleh kualitas serta kuantitas hidangan. Kualitas hidangan menunjukkan adanya semua zat gizi yang diperlukan tubuh di dalam susunan hidangan dan perbandingannya yang satu terhadap yang lain.

Sependapat dengan penelitian Lailatul Munawaroh (2006) bahwa tingkat pengetahuan ibu tentang gizi yang tinggi dapat mempengaruhi pola makan balita yang pada akhirnya akan mempengaruhi status gizi balita. Dengan pengetahuan yang baik, seorang ibu dapat memilih dan memberikan makan bagi balita baik dari segi kualitas maupun kuantitas yang memenuhi angka kecukupan gizi bagi balita. Asupan makanan yang sesuai dengan angka kecukupan giziyang dibutuhkan oleh seorang balita dapat mempengaruhi status gizi balita (Melyani, 2018) 
Setelah peneliti melakukan penelitian dan mendapatkan hasil tidak ada hubungan yang signifikan antara pengetahuan tentang gizi seimbang dengan status gizi sehingga di dapatkan juga bahwa status gizi balita dengan pengetahuan ibu tidak terdapat perbedaan yang signifikan. Hal ini juga bisa di sebabkan karena konsumsi makanan berpengaruh terhadap status gizi seseorang. Kondisi status gizi baik dapat dicapai bila tubuh memperoleh cukup zat zat gizi yang akan digunakan secara efisien, sehingga memungkinkan terjadinya pertumbuhan fisik, perkembangan otak, kemampuan kerja untuk mencapai tingkat kesehatan optimal.

\section{Kesimpulan}

Berdasarkan hasil penelitian yang telah dilakukan, maka dapat disimpulkan bahwa tidak ada hubungan yang signifikan antara pengetahuan tentang gizi seimbang dengan status gizi. Diharapkan Pukesmas Pal III bisa memberikan penyuluhan pada saat posyandu dengan memberikan materi tentang pentingnya konsumsi gizi seimbang pada balita dan menganjurkan kepada ibu-ibu agar melakukan pemantauan status gizi pada balita secara berkala di tempat pelayanan kesehatan.

\section{Daftar Pustaka}

Adisasmito, W. 2007. Sistem Kesehatan. Jakarta: PT. Raja Grafindo Perseda

Almatsier Sunita. 2002. Prinsip Dasar Ilmu Gizi. Jakarta:PT Gramedia Pustaka Utama

Arikunto Suharsimi. 2011. Prosedur Penelitian. Jakarta:PT Rineka Cipta
Argia Intan, dkk. 2012. Gizi Reproduksi. Yogyakarta: Fitramaya

Beck, M.E.2002. Ilmu Gizi Diet. Jakarta: Yayasan Esssentia Medica

Data Informasi Profil Kesehatan Indonesia Tahun 2016

Data Pukesmas Pal III Tahun 2018. Tentang tinggi badan dan berat badan Balita

Departemen Kesehatan RI, 2002. Tentang Berat Badan/Tinggi Badan (Direktorat Gizi Masyarakat 2002)

Dharma Kelana Kusama. 2011. Metodologi Penelitian Keperawatan. Jakarta: CV. Trans Info Media

Sibagariang Eva Ellya. 2010. Kesehatan Reproduksi Wanita. Jakarta: Trans Info Media

Hasdianah, dkk. 2014. Gizi, Pemantapan Gizi, Diet, Dan Obesitas.Yogyakarta: Nuha Medika

Irianto, koes.2014. Gizi Seimbang Dalam Kesehatan Reproduksi. Bandung: ALPABETA

Jafar.2010. Status Gizi.Jakarta: PT. Gramedia Pustaka

Kurniawati, Erni. 2011. Hubungan Tingkat Pengetahuan Ibu Tentang Gizi Dengan Status Gizi Balita Di Kelurahan Baledono, Kecamatan Purworejo, Kabupaten Purworejo. Http://ejournal.akbid-purworejo.ac.id, diakses: tanggal 25Febuari 2018, jam 9:17 WIB

Marmie. 2013. Gizi Dalam Kesehatan Produksi. Yogyakarta: Pustaka Pelajar

Maryunani Anik. 2010. Ilmu Kesehatan Anak Dalam Kebidanan. Jakarta: CV. Trans Info Media

Mudhairoh, Lina. 2008. Hubungan Tingkat Sosial Ekonomi Keluarga Dan 
Pengetahuan Gizi Ibu Dengan Status Kadarzi Di Desa Subah Kabupaten Batang Tahun 2008. Lib.unnes.ac.id, diakses: tanggal 22 Maret 2018, jam 22:23 WIB

Munawaroh, lailitul. 2016. Hubungan Antara Tingkat Pengetahuan Gizi Ibu, Pola Makan Balita Dengan Status Balita Di Wilayah Kerja Pukesmas

Kedungwungi II Kabupaten Pekalongan Tahun 2016. http//wwweskripsi.stikesmuh-pkl.ac.id, diakses: tanggal 22 Maret 2018, jam 22:19 WIB

Notoatmodjo Soekidjo. 2010. Promosi Kesehatan. Jakarta: Rineka Cipta

Profil Kesehatan Kalimantan Barat Tahun 2015

Melyani, A. (2018). Hubungan antara Tingkat Pengetahuan Ibu Tentang Gizi dengan Status Gizi Balita di Pukesmas Pal III Kabupaten Pontianak Tahun 2018. Jurnal Kebidanan, $8(1)$. https://www.neliti.com/publications/3268 68/hubungan-antara-tingkatpengetahuan-ibu-tentang-gizi-denganstatus-gizi-balita-d\#cite

Sediaoetama achmad djaeni. 2010. Ilmu Gizi Untuk Mahasiswa Dan Profesi. Jakarta: Dian Rakyat Sujarweni Wiratna.
2014. Metodologi Penelitian Keperawatan. Yogyakarta: Gava Media

Supariasa Dewa Nyoman. dkk. 2002. Penilaian Status Gizi. Jakarta: Buku Kedokteran EGC

Susila dan Susyanto. 2014. Metode Penelitian Epidemiologi. Yogyakarta: Bursa Ilmu

Susilowati, Endang. 2010. Hubungan Tingkat Pengetahuan Ibu Tentang Gizi Balita Dengan Status Gizi Balita Di Wilayah Kerja Puskesmas Gajah 1 Demak. http://www.google.co.id, diakses: tanggal 20 Maret 2018, jam 9:25 WIB

Wahyani. 2015. Hubungan Tingkat Pengetahuan Ibu Tentang Gizi Balita Dengan Status Gizi Balita Di Wilayah Kerja Puskesmas Pleret, Bantul, Yogyakarta. https://wwwgoogle.co.id. diakses: tanggal 20 Maret 2018, jam 9:25 WIB 